日臨外会誌 $61 （ 1), 156-160,2000$

症例

腸閉塞にて発症した回腸原発神経内分泌細胞癌肝転移例

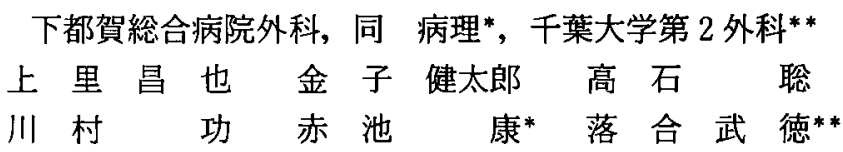

症例は41歳，女性. 腹痛を主訴に受診し，イレウス症状を認めたため入院した。小腸 腫場によるイレウスと肝転移の疑いて，回腸部分切除肝外側区域切除抽よび胆摘術を施 行した．回腸と肝の腫瘍は病理標本上カルチノイドと比べ核が大きく不整形で, 未分化 癌様の組織像を示した.グリメリウス染色・S-100・SNE 染色がいずれも陽性で, 電子 顕微鏡検査では神経分泌顆粒を認めた，これより神経内分泌細胞由来の腫場と考え，肝 転移を伴う回腸原発神経内分泌細胞癌の診断を得た。現在外来にて残肝腫場に対し肝動 注を施行中である。

索引用語：神経内分泌細胞癌，小腸腫瘍，肝転移

\section{緒 言}

神経内分泌細胞由来の腫場の内, 病理学的に核が比 較的大きく不整形で，大結節状あるいはシート状に增 殖し，末分化癌様の形態を示すものを神経内分泌細胞 癌とし，近年カルチノイドと区別して考えられるよう になった.カルチノイドと異なり非常に悪性度が高く, 早い段階より他臟器への転移を来たし極めて予後不良 である．また小腸の悪性腫場は稀な疾患とされている が，その中でも神経内分泌細胞癌はこれまで本邦報告 例として 2 例をみるのみである. 今回われわれは, 腸 閉塞にて発症し多発性肝転移のみられた回腸原発神経 内分泌細胞癌の 1 例を経験したので, 若干の文献的考 察を加え報告する。

$$
\text { 症例 }
$$

症例：41歳, 女性.

主訴：腹痛。

既往歴：昭和61年,卵巣要腫にて左卵巣摘出術施行.

家族歴：特記すべきことなし．

現病歴：平成 10 年 7 月 21 日朝より上腹部を中心とし た腹痛が出現, 近医を受診し急性胃腸炎の診断にて経 過観察となった。翌22日イレウス症状が出現したため, 当院紹介入院となった。

入院時現症：体格はやせ形，貧血や黄疸は認めず. 体温は $36.3^{\circ} \mathrm{C}$. 左下腹部に軽度圧痛を認めたが，筋性

1999年 6 月21日受付 1999年10月20日採用
防御はなかった。腹部腫㾇や表在リンパ節も触知しな かった.

入院時一般検査：白血球が $10,900 / \mathrm{mm}^{3}$ と軽度上㫒 を認めたが，他に異常值なし．腫瘍マーカーは CEA・ CA19- 9・AFP・CA125など全て正常範囲内であり, また $\mathrm{B}$ 型・C 型肝炎ウイルスマーカーは陰性であっ た.

腹部単純 $\mathrm{X}$ 線所見：小腸に二ボーを認めた．大腸の ガス像は認めなかった。

腹部超音波所見：肝藏 S3に径 $11.5 \mathrm{~mm}, \mathrm{~S} 7$ に径 20.5 $\mathrm{mm}$ ，他にも小さな低から等エコーを示す腫瘤を多数 認めた。

上腹部 CT 所見：early phaseにて造影され, late phase にて wash out される多発性肝埂瘤を認めた。り ンパ節の腫脹は認めなかった。

骨盤 CT 所見：右下腹部に淡染される直径約 $5 \mathrm{~cm}$ の腫瘤性病変を認めた。

イレウス管造影所見：イレウス管約 $180 \mathrm{~cm}$ 挿入に て造影を行ったところ，回腸に完全閉塞を認めた（図 1 a).

腹部血管造影所見：多発性に動脈相にて濃染される 腫瘤陰影を認めた（図 1 b ).

肝腫瘍生検：類円型の比較的小型の核と好酸性ない し淡明な細胞質を有し,大結節状の増殖を示していた。 免疫染色にて PAS (+)・ジアスターゼ消化 PAS (-). EMA (epithelial membrane antigen) 弱陽性・LCA 


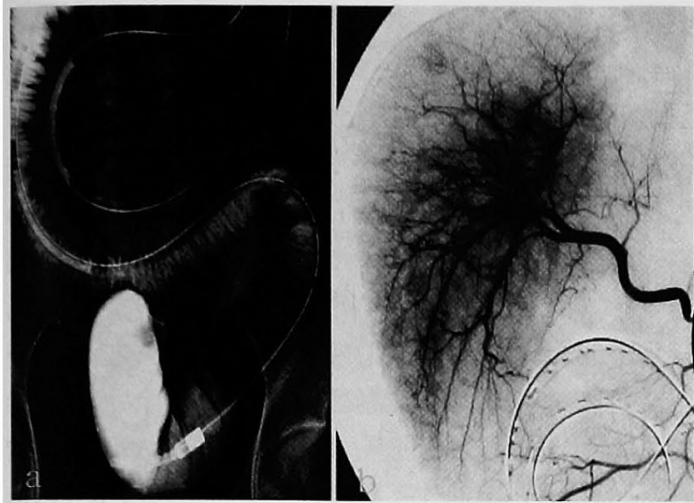

図 1 a イレウス管造影：回腸に完全閉塞を認めた。 b 腹部血管造影：上腸間膜動脈からの造影である. 右および中肝動脈が造影されている．多発性に動脈相 にて浱染される腫瘤陰影を認めた。

(一)であり, 腎・女性器や肺などの淡明細胞癌の肝転 移，神経内分泌腫瘍あるいは肝細胞癌を疑わせた。

以上より小腸, 腎あるいは女性器の腫瘍の肝転移, または肝細胞癌を疑い，8月13日手術を施行した。

手衍所見：回腸末端より約 $60 \mathrm{~cm}$ の口側の回腸内に 径 $5 \mathrm{~cm}$ 大の腫瘤を認め,これを先進として腸重積を 起こしていた，所属リンパ節は10個程腫脹していたが 柔軟であった.術中肝エコーでは多発性に腫瘤を認め, 特に S3には径約 $20 \mathrm{~mm}$ 大の腫瘤が 2 個みられた。右肝 動脈は上腸間膜動脈より，左肝動脈は腹腔動脈より分 岐しており術後の TAI (transcatheter arterial injection) も考慮し, 回腸部分切除, 肝外側区域切除および 胆摘術を施行した。子宮, 卵巣, 腎臓に腫瘤は認めな かった。

切除標本, 病理組織学的所見: 回腸腫瘍は径 $8 \times 5$ $\mathrm{cm}$ の大きさで有茎性カリフラワー状を呈し，黄色調 弾性を有する腫瘤であった(図 2 a)。割面では粘膜は 正常に保たれており，粘膜下に白色調腫場を認めた (ss)（図 2 b). 組織像では線維血管性の瀻細な間質を 伴い, 腫瘍細胞は大結節状の配列を示していた（図 3 a).またリンパ管や静脈への浸潤は認められなかっ た. 特殊染色では腫湯細胞がグリメリウス染色・S$100 \cdot$ NSE (neuron-specific enolase) 染色陽性であり 神経内分泌細胞由来の特徵を示した（図 $3 \mathbf{b}$ ). また EMAでも軽度の陽性所見を認めたことから，一部上 皮への分化を示すことがわかった．電子顕微鏡検査で は細胞質内に Dense core granules を認め, 神経分泌 顆粒の特徵を示した（図 4 ），肝腫湯は境界明瞭なやゃ
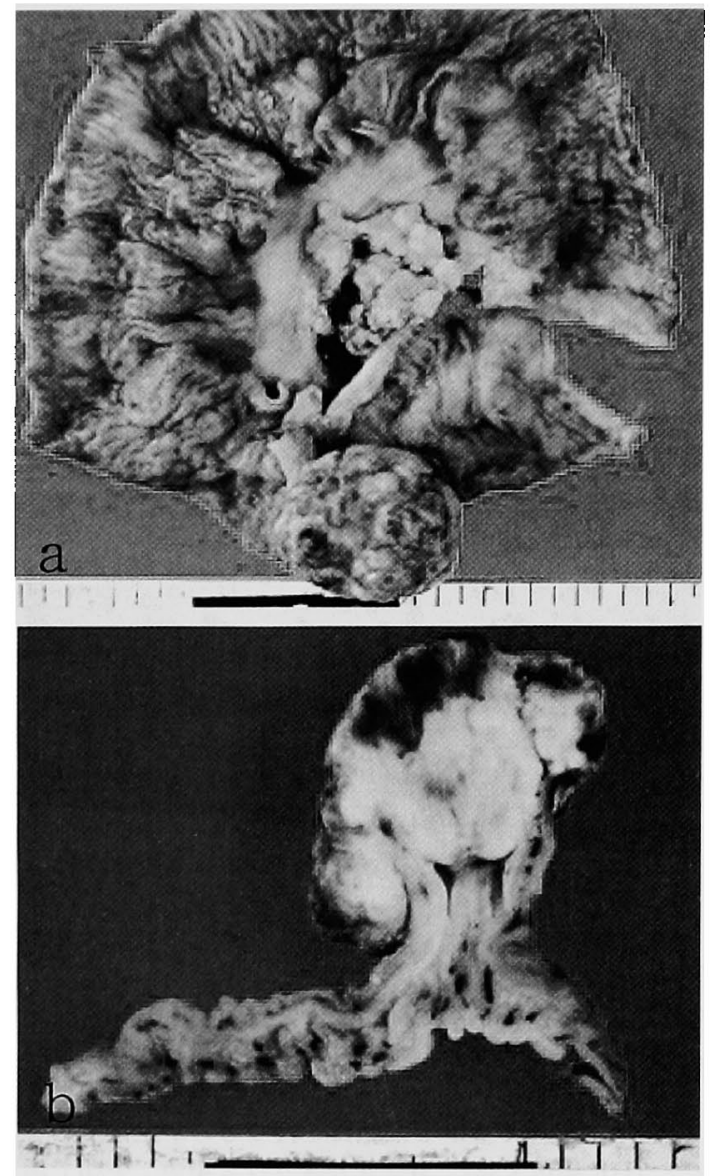

図 2 回腸切除標本：a 肉眼像：腫韵は径 $8 \times 5 \mathrm{~cm}$ の大きさで有茎性カリフラワー状を呈し, 黄色調弾性 を有する腫瘤であった， b 割面像；割面では粘膜は 正常に保たれているが，粘膜下に白色調腫瘍を認めた。

白色調の柔らかい腫瘤で，組織像では回腸腫湟よりは やや小型の腫瘍細胞であるが極めて類似していた。

以上より多発性肝転移を伴う回腸原発神経内分泌細 胞癌の診断となった．術後セロトニン，七スタミンな ど血中ホルモンを測定したが，異常值は認められなか った.

術後経過：術後 3 週目の 9 月 4 日に肝血管造影を施 行したところ, 術前に比し腫崵の急速な増大を認めた。 このため TAI として右肝動脈より FAM ( 5 -FU 430 $\mathrm{mg}, \mathrm{ADR} 26 \mathrm{mg}$, MMC $3.5 \mathrm{mg})$, リピオドール $3 \mathrm{ml}$ を注入し 9 月13日退院した. TAI 2 週間後の CT で, 転移巣へのリピオドールの良好な集積を認めた。9月 30 日再入院，10月 2 日動注りザーバーを右肝動脈へ挿 入し10月10日退院した。外来でリザーバーより FAM 


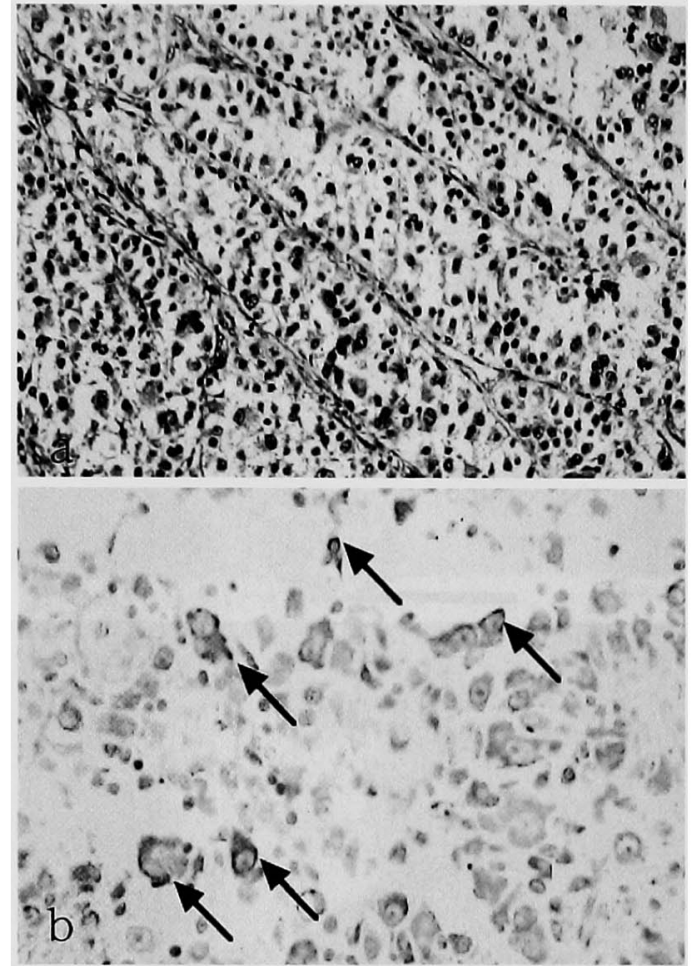

図 3 回渴腫㿋病理組織所見：a 病理所見；腫瘍細 胞は胞巣状に増殖しておう，緎細な線維血管性の間 質に境されている．また腫瘍細胞は中型で類円型の 核と好酸性で豊かな細胞質を持つものが主体である (HE 染色 $\times 33)$ ）， グリメリウス染色：矢印で示 すように陽性所見を認めた（×132）。

( 5 -FU $330 \mathrm{mg} / \mathrm{m} 2 / \mathrm{qw}$, ADR $20 \mathrm{mg} / \mathrm{m} 2 / \mathrm{q} 4 \mathrm{w}, \mathrm{MMC}$ $2.7 \mathrm{mg} / \mathrm{m} 2 / \mathrm{q} 2 \mathrm{w})$ を 4 クール施行した. FAM 3 クール 後の CT では, 残肝腫瘍はやや縮小傾向であった。平 成11年 4 月 30 日現在他部位への新たな転移は認められ ておらず，外来通院治療中である。

\section{考 察}

以前よりカルチノイドとして分類されていた腫瘍の 中に, 悪性度が極めて高く，予後不良のものがあった。 カルチノイドは病態として低悪性度に位置づけられて おりこのような腫演は悪性カルチノイドと呼ばれて いた1). Gould ${ }^{21}$ は1987年 Hematoxylin and eosin(H -E) 染色からは肺小細胞癌に類似するものの, 電子顕 微鏡にて内分泌顆粒を証明でき, 悪性度が高く予後不 良の癌を神経内分泌細胞癌 (neuroendocrine carcinoma）と定義してカルチノイドから区別した．神経 内分泌細胞癌の発生母地は，カルチノイドと同椂に全

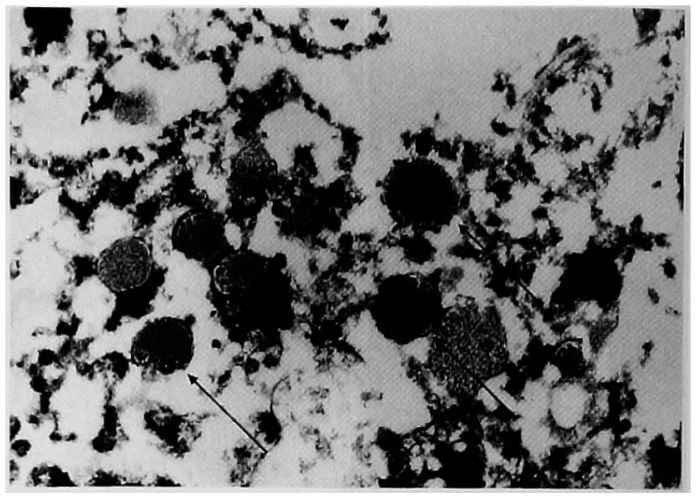

図 4 電子顕微鏡検査 : 細胞質内に Dense core granules を認める (矢印). size は200〜300nmである.

表 1 神経内分泌細胞演とカルチノイドの組織学的な特街

\begin{tabular}{ccc}
\multicolumn{2}{c}{ 神経内分泌細胞癌 } & カルチノイド \\
\hline 細胞異型度 & 高異型度 & 低異型度 \\
\hline $\mathrm{N} / \mathrm{C}$ 比 & 高 & 低 \\
\hline 核分裂細胞 & 頻繁 & 極稀 \\
\hline 脈管侵裂 & 頻繁 & 無 \\
\hline グリメリゥス染色 & ++ & +++ \\
\hline クロモグラニン染色 & ++ & +++ \\
\hline NSE & ++ & +++ \\
\hline
\end{tabular}

身に広く散在性に分布する神経内分泌細胞であり, 表 $1{ }^{3}$ に示すようにグリメリウス染色・クロモグラニン 染色・NSE は互いに陽性でる.カルチノイドは小型 で均一な核と弱好酸性微細顆粒状の細胞質を持ち, 核 分裂像を示すことはほとんどなく，索状，リボン状と いつた特徵的な細胞配列を示す。一方神経内分泌細胞 癌は弱好酸性細胞質と，染色質に富み，大型～小型の 円型～多型核と分裂像を示す腫晅細胞加ら成り，大結 節状, シート状に増殖する，以前悪性カルチノイドや 未分化癌とされていたもののなかに神経内分泌細胞癌 が相当数あると思われる. 以上より悪性カルチノイド は嵈密に定義されておらず，慣用的に用いられた名称 であるため，引用するに好ましくないと考える．さら に神経内分泌細胞癌とカルチノイドは異なる組織学的 特徴をもつこと．また神経内分泌細胞癌の診断, 治療 法の確立のためにも今後カルチノイドと区別されなけ ればならないと思われた。

今回われわれが経験した症例は, H-E 染色では低分 化, 未分化癌様の像を呈し, 部分的には淡明細胞癌を 
も思わせた。しかしクロモグラニン染色にては陽性所 見を認めなかったものの,グリメリウス染色, NSEそ してS-100染色にて陽性であった。また電子顕微鏡検 查で内分泌顆粒を認めたことから，神経内分泌細胞癌 の診断となった．また小腸腫場の EMA に陽性所見を 㑇めたことは，扁平上皮化生を示している。これは岩 判(らや神藤包らがすでに指摘しているように，神経内 分緒細胞癌の発生母地や分化を考える上で興味深いと 考えられた。本症例の小腸腫湯切除標本では粘膜は正 常に保たれていたことから，多分化能幹細胞または幼 若内分视細胞から発生し粘膜下で増殖，その後一部扁 平上皮化生を示したと考えられる。

1988年から1998年までの11年間に，自験例を含めて 組織学的に明らかに神経内分泌細胞癌と診断された 81 例を集計した。また1986年に曾我6)らにより報告され た本邦カルチノイド腫摥の1,342例のデーターを引用 し,神経内分泌細胞癌とカルチノイドを比較検討した。 男女比は神経内分泌細胞癌が 4 対 6 で女性に多くみ られたのに対して，カルチノイドは 6 対 4 と男性に多 かった。これは神経内分泌細胞癌の原発巣が，後で述 べるように産婦人科領域に多いことによると考えられ る. 年齢分布では神経内分泌細胞癌は 20 歳代から80歳 代と広く分布し, 50 歳代は 22 人を占めピークであった. 本症例は41歳でありやや若年であった，また神経内分 泌細胞癌の平均年齢は58歳で，カルチノイドの50.7葴 との有意差は認められなかった。

術前診断で神経内分泌細胞癌と確定されたものは 9 例（11\%）であった。これは先にも述べたように神経 内分泌紐胞癌はカルチノイド，低分化腺癌そして未分 化癌の範嗃に入れられることが多かったからである う. 神経内分泌細胞癌の診断手順は，本症例と同様に 低分化腺癌あるいは末分化癌の像を認め，銀染色や免 疫染色にて神経内分泌細胞癌の可能性が示唆された場 合には，電子顕微鏡検索を実施して内分泌顆粒を見つ け確定診断する方法が現在最も広く支持されてい $3^{718)}$.

神経内分泌細胞癌の原発巣は虐婦人科領域の臟器に 最も多く，その中でも特に子宮頸部が19例（23.5\%） を占めた，消化器領域は，産婦人科領域に次いで 2 番 目に多く18例（22.2\%）であった。その中でも大腸は 8 例 (9.9\%) て小腸は僅か 3 例 $(3.7 \%)$ にみられる のみである.カルチノイドでは消化器科領域が $69.2 \%$ と大部分を占め，その中でも大腸，胃が26.9\%，19.3

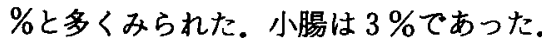

遠隔転移については，神経内分泌細胞癌が $47 \%$ と高

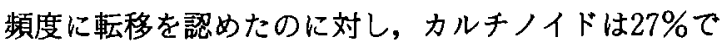
あった．神経内分泌細胞癌は肝に $66 \% ，$ 骨に $29 \%$ と血 行性転移をしやすい傾向がみられた。一方カルチノイ ドはリンパ節転移が $61 \%$ にみられ，リンパ行性転移し やすいと考えられた。

カルチノイドを含めた神経内分泌腫瘍の治療は，原 発巣がわかっていて切除可能なものは手術が基本であ り, 術後化学療法を加える場合もある的とされている. しかし神経内分泌細胞癌に関してはまだ症例も少な く,有効な治療法が確立されていないのが現状である。 本症例も原発巣である小腸切除を行い，残肝腫湯には 動注化学療法を施行している.

予後に関しては, 神経内分泌細胞癌の over all にお ける 5 年生存率が $15.9 \%$ でるが，Kaplan Meier 法 による生存曲線ては殆ど 1 年以内に死亡しており予後 不良であった。カルチノイドでは小腸カルチノイドの 5 年生存率が, 肝転移陰性例 $72 \%$, 肝転移陽性例 34.9 \%, そして全体として $59 \%$ であった ${ }^{10)}$.

\section{結 語}

腸閉塞にて発症した回腸原発神経内分泌細胞癌肝転 移例を経験したので報告した，神経内分泌細胞癌は力 ルチノイドやその他の癌と区別され，今後有効な治療 法の確立へと結び付くことを期待する。

\section{謝辞}

病理学検討に際し, 直接御指導頂きました千葉大学病理 学第 2 講座近藤洋一郎先生に感謝致します。

\section{文献}

1）木村伯子：覀性カルチノイドか神経内分泌細胞癌 か. 医のあゆみ $177: 767-771,1996$

2) Gould VE, Chejfec G: Neuroendocrine carcinomas of the colon. Am J Surg Pathol $2: 31$ $-38,1978$

3) Kimura N, Nagura $\mathrm{H}$ : A comparative study of neuroendocrine carcinoma and carcinoid tumor with special reference to expression of HLADR antigen and PCNA. Zentralbl Pathol 139 171-175, 1993

4）岩㴊三哉，渡辺英伸，石原法子他：消化管のカル チノイドと内分泌細胞癌の病理一その特徴と組織 発生一。臨消内科 $5: 1669-1681,1990$

5）神藤英二, 望月英隆, 寺畑信太郎他：腺癌, 扁平 上皮癌の成分をともなった盲腸内分秘細胞癌の 1 例. 日消外会誌 $30: 2210-2214,1997$ 
6）曾我 淳：本邦 carcinoid 腫瘍一1,342症例の統 計学的分析一. 外科 $48: 1397-1409,1986$

7）大塚正彦，加藤 洋：大腸の低・未分化癌の臨床 病理学的検討一分類および内分泌細胞癌との関連 について。日消外会誌 $25 ： 1248-1256 ， 1992$

8）内村正幸，木田栄郎，脇 慎治他：肛門管内分泌 細胞癌，上銘外喜夫編，別冊日本臨床，領域別症
候群, シリース 6 , 消化管症候群 (下巻), 日本臨 床社，大阪，1994，p786-789

9）岩田 烹，兼松隆之：カルチノイド腫瘍肝転移例 に対する治療. 内分泌外科 $11: 245-250,1994$

10) Stroel WE, Talpos G, Eckhauser F, et al : Surgical Therapy for Small-Bowel Carcinoid Tumors. Arch Surg 118:391-397 1983

\title{
A CASE OF NEUROENDOCRINE CARCINOMA OF THE ILEUM WITH MULTIPLE LIVER METASTASIS PRESENTED WITH INTESTINAL OBSTRUCTION
}

\author{
Masaya UESATO, Kentaro KANEKO, Satoru TAKAISHI, Isao KAWAMURA, \\ Yasushi AKAIKE* and Takenori OCHIAI** \\ Departments of Surgery and Pathology*, Shimotsuga General Hospital \\ * Second Department of Surgery, Chiba University School of Medicine
}

A 41-year-old woman was admitted to the hospital because of intestinal obstruction. An ileus tube was inserted and we found out a complete obstruction of the ileum. Ultrasonography, CT scan and angiography visualized multiple liver tumors. With a suspicion of intestinal obstruction due to an ileum tumor and multiple liver metastasis, a partial resection of the ileum, a lateral segmentectomy and a cholecystectomy were performed. Histological examination revealed that the tumor of the ileum was atypical poorly differentiated adenocarcinoma (ss, ly0, v0, no) and the tumor cells of both the ileum and liver had more undifferentiated appearance than carcinoid. Immunohistochemical stainings (grimelius, S-100, NSE) were positive, indicating that they have neuroendocrine differentiation. Electron microscopy revealed dense core granules. Therefore, it was diagnosed as neuroendocrine carcinoma of the ileum with multiple liver metastasis.

After discharge, intra-arterial chemotherapy (FAM) was started on ambulant basis in the treatment of remaining liver tumors. The patient is alive 8 months after the operation with no sign of growing of the remnant tumors. 